\title{
Badacz jako artysta, artysta jako badacz. Założenia metodologiczne działań artystycznych w procesie badawczym ABR (art-based-research)
}

\author{
Joanna Bielecka-Prus \\ UMCS
}

DOI: http://dx.doi.org/10.18778/1733-8069.16.2.02

Słowa kluczowe: sztuka w badaniach jakościowych, ABR, metodologia badań jakościowych

\begin{abstract}
Abstrakt: Postmodernizm, podważając założenia epistemologiczne pozytywizmu i hermeneutyki, wywarł ogromny wpływ na metodologię badań jakościowych. Zatarciu ulegają nie tylko gatunki, ale także granice między dyscyplinami, tak jak to jest w przypadku działań artystycznych w procesie badawczym (ABR - art-based-research), w których badacz posługuje się środkami artystycznymi na różnych etapach zbierania, analizy i prezentacji danych. Problem łączenia sztuki z działaniami badawczymi można rozpatrywać na wielu płaszczyznach. W tym artykule chciałabym skupić się na: 1 . Wyjaśnieniu głównych założeń epistemologicznych i metodologicznych badań opartych o sztukę; 2. Omówieniu funkcji ABR w społecznym konstruowaniu wiedzy; 3 . Wskazaniu kryteriów, które pozwalają ocenić jakość ABR, oraz trudności, jakie wiążą się z prowadzeniem tego typu badań.
\end{abstract}

Joanna Bielecka-Prus, doktor socjologii, pracuje w Instytucie Socjologii Uniwersytetu Marii Curie-Skłodowskiej. Jej zainteresowania naukowe skupiają się wokół metodologii badań jakościowych (w tym badania wizualne, performatyka, analiza dyskursu), współczesnych teorii socjologicznych, socjologii migracji oraz socjologii edukacji. Jest autorką i współautorką ponad pięćdziesięciu publikacji naukowych w języku polskim i angielskim.

\section{Adres kontaktowy:}

Instytut Socjologii UMCS

pl. Marii Curie-Skłodowskiej 4, 20-031 Lublin e-mail: j.bielecka.prus@gmail.com 
Sztuka jest magią: rodzi się z kłamstwa,

będąc prawdą.

Prendergast 2006: 376 [tłum. własne]

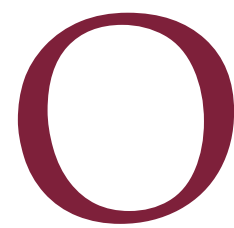

drzucenie paradygmatu pozytywistycznego, zamykającego badacza w wąskiej klatce empiryzmu, i przyjęcie perspektywy humanistycznej, akceptującej osobliwości „nauk o duchu” (Geistwissenschaften), otworzyło naukom społecznym nowe drogi eksploracji świata ludzkiego. Postmodernizm, poważając założenia epistemologiczne pozytywizmu i hermeneutyki, wywarł ogromny wpływ na metodologię badań jakościowych. Dekonstrukcja, a nawet destrukcja tak kluczowych dla badań pojęć jak na przykład „znaczenie”, „obiektywność”, „prawda” skłoniła badaczy do formułowania nowych paradygmatów badawczych. Poszukiwano sposobów wyjścia z obwieszczanych raz po raz kryzysów reprezentacji (Clifford, Marcus 1986), legitymizacji i praktyki (Denzin, Lincon 2009), formułując programy uzdrawiania nauki pod szyldem nowych zwrotów (np. kulturowego, językowego, dramaturgicznego, narracyjnego, wizualnego, performatywnego). Na gruncie metodologii postulowano „zmącenie gatunków”, zacierając różnicę między stylami, rolami badacza, badanego i odbiorcy, aby podważać utrwalone dyskursywnie relacje władzy, poszukiwać nowych sposobów poznawania rzeczywistości wymykającej się racjonalnym schematom indukcyjno-dedukcyjnym. W rezultacie gwałtownych zmian, które obejmowały fazę tradycyjnego realizmu, modernizmu, rozmytych gatunków, kryzysów, eksperymentalnego pisania i badań posteksperymentalnych (Denzin, Lincon 2009), badacze rzeczywistości społecznej mogą czuć się zagubieni w gąszczu metodologii, braku rygorów proceduralnych, $\mathrm{z}$ ich anything goes $\mathrm{w}$ imię nieskończonych transgresji. Sprawa jeszcze bardziej się komplikuje, gdy zatarciu ulegają nie tylko gatunki oraz role badacza i badanego, ale także granice między dziedzinami poznawczymi, tak jak to jest w przypadku działań artystycznych w procesie badawczym (ABR - art-based-research).

Jeśli jednak przyjrzymy się dokładniej problematyce powiązań sztuki i nauki, zobaczymy, że granice między nimi nie są wyraźnie wytyczone. Nie chodzi tu jedynie o to, że sztuka "pozostaje zawsze składnikiem życia społecznego" (Golka 2008: 30), który kształtuje procesy społeczne i jest przez nie kształtowany. Socjologowie poszukują czynników społecznych, które modelują formy sztuki, jej treści, reżimy tworzenia i odbioru. W dziełach sztuki można znaleźć głębokie analizy procesów społecznych, które mogą bardzo trafnie wyjaśniać interesujące socjologów zjawiska (Golka 2008). Można zatem powiedzieć, że sztuka i zjawiska społeczne wzajemnie się „oświetlają", nie tracąc jednak własnej odrębności. Jednakże zbyt silna integracja sztuki i nauki może budzić pewne obawy, nawet wśród zwolenników badań interdyscyplinarnych czy transdyscyplinarnych, którzy obawiają się spadku prestiżu nauki porzucającej pozytywistyczne kanony poznania naukowego. Dlatego też działania artystyczne w procesie badawczym traktowane są z nieufnością, pojawiają się wątpliwości, na ile mamy tu wciąż do czynienia z nauką, jakie kryteria naukowości one spełniają jaką mają wartość poznawczą.

Problem ten można analizować na kilku płaszczyznach. Nauka jest elementem systemu kultury o nieostrych granicach, a inne systemy kultury (np. ekonomia) w pływają na to, co dzieje się na polu nauki, a także podlegają jego wpływom. Wpływ nauki na sztukę jest widoczny na przykład, gdy weźmiemy pod uwagę techniki tworzenia dzieł artystycznych, 
z kolei wpływ sztuki na naukę budzi obawy, a ta jednostronna hermetyzacja wynika z przyjętego ideału nauki jako poznania czysto rozumowego. Ale nie tylko kwestie wzajemnych uwarunkowań są tu istotne. Problemem fundamentalnym jest wieloznaczność terminu nauka rozumianego jako pewien typ poznania lub/i jego rezultat. Poznanie naukowe powinno być systematyczne, metodyczne, dostarczające uzasadnionych wyjaśnień i nowej wiedzy na temat otaczającej nas rzeczywistości (Kamiński 1992). Sztuka, nawet jeśli przypisze się jej pewne walory poznawcze (np. T. W. Adorno), wraz z jej nieusystematyzowanymi wglądami i iluminacjami, abdukcyjnie formułowanymi wnioskami iekspresyjnym językiem wydaje się być zaprzeczeniem poznawania naukowego. Przeciwnicy ABR twierdzą, że połączenie tych przeciwieństw nie stworzy nowej, lepszej jakości. Zwolennicy uważają, że problem jest źle postawiony, bowiem z założenia dychotomizuje działania artystyczne i badawcze, tworząc dwa nieprzenikalne i spolaryzowane obszary działalności człowieka, gdy faktycznie tworzą one kontinuum (np. Eisner 1981). Eisner (2006) zauważa, że tylko na pierwszy rzut oka sztuka $\mathrm{w}$ procesie badawczym może być postrzegana jako sprzeczność czy wręcz oksymoron, gdyż nauka i twórczość artystyczna opierają się na odmiennych wartościach: nauka na logice i racjonalności, sztuka zaś na uczuciach. Jest to jednak sprzeczność pozorna, jeśli pojęcie badania zdefiniujemy szerzej - jako doświadczanie i rozumienie ludzkiego życia w zróżnicowanych kontekstach. W takim ujęciu badanie nie jest wyłącznie zmonopolizowane przez naukę: artysta może być badaczem, a badacz może posługiwać się formami artystycznymi. Doświadczenie antropologiczne i estetyczne są splecione ze sobac poprzez oko, a antropologia to „sztuka inteligentnego widzenia" (Czaja 2004: 57). Stanisław Kamiński (1992), metodolog nauk, wymienia wiele podobieństw łączących naukę i sztukę: istotna rola procesu twórczego, estetyzacja wytworów, która wnauce wyraża się dążeniem do elegancji i prostoty wywodów, dążenie do oryginalności, zauważając jednakże widoczne różnice. Dla nauki nadrzędną wartością jest prawda, w sztuce zaś wywoływanie przeżyć estetycznych, nauka buduje swoje systemy wiedzy w oparciu o statystyczną generalizację, sztuka zaś poprzez deformację zastanych form, skupienie się na idiosynkrazji przeżyć. Nie mamy zatem do czynienia z tożsamością dziedzin twórczych ani w celach, ani w metodzie. Podobne tezy możemy spotkać wśród zwolenników ABR. Działania artystyczne w procesie badawczym nie dążą do tego, aby zastąpić już prawomocne metody poznania czy wyprzeć obowiązujące paradygmaty. W tym sensie same nie tworzą nowego metodologicznego systemu, który może samodzielnie rozwijać poznanie naukowe. Są jednakże jedną z metod gromadzenia danych, ich interpretowania, a także prezentacji analiz. Obawy, że ABR wyprze inne metody, a w ten sposób zagrozi nauce, są zupełnie nieuzasadnione i wynikają z braku wiedzy o epistemologicznych i metodologicznych założeniach działań artystycznych w procesie badawczym, funkcji, jaką pełnią w procesach wiedzotwórczych. Celem tego artykułu jest wskazanie wartości poznawczych i społecznych ABR, a także problemów badawczych, jakie możemy napotkać, posługując się ABR w badaniach społecznych.

\section{Nowy paradygmat w badaniach jakościowych?}

Norman Denzin i Yvonna S. Lincoln (2009) w zaproponowanej periodyzacji rozwoju badań jakościowych umiejscawiają ABR w fazie badań posteksperymentalnych (1995-2000), w której odrzuca się tradycyjne podejście do badań jakościowych. Bada- 
nia te są pewnym typem brikolażu, w którym łączy się zróżnicowane dane i gatunki. Nie mogą być one systemem abstrakcyjnych pojęć oderwanych od rzeczywistości. Powinny one jeszcze w większym stopniu, niż było to w badaniach realizowanych we wcześniejszych fazach, zwrócić się ku doświadczeniom, emocjom i znaczeniom, jakie są przypisywane sytuacjom życiowym przez przeżywających świat ludzi. Ponadto, czerpiąc z teorii krytycznych, ABR nie może zatrzymać się jedynie na opisie świata, ale ma dążyć do jego zmiany na lepsze. Nie negując słuszności tej periodyzacji, należy pamiętać, że już w poprzednich fazach rozwoju badań jakościowych pojawiły się prekursorskie projekty badawcze zwiastujące zmianę.

Zaproponowane uporządkowanie chronologiczne pomija fakt, że granica dzieląca naukę i sztukę nie zawsze była wyraźnie wydzielona, czego dowodem jest działalność Leonarda da Vinci, który byłnie tylko artysta, ale także konstruktorem. Związek między sztuką a literaturą był wyraźnie widoczny w pracach filozofów Denisa Diderota i Jacquesa Roussseau, którzy pisali zarówno rozprawy filozoficzne, jak i powieści. Dostrzegali oni bowiem ograniczenia tradycyjnych traktatów filozoficznych i poszukiwali form, które lepiej opiszą wyselekcjonowane aspekty życia społecznego (Lawrence-Lightfoot 2005), a ponadto będą zrozumiałe dla szerszego grona odbiorców, wzmacniając walor dydaktyczny dzieł, cenny w epoce Oświecenia. Pisarze tacy jak Honoré de Balzac, Gustave Flaubert czy Emil Zola twierdzili, że uprawiają science sociale, a literatura $\mathrm{w}$ tym czasie stała się "groźnym rywalem" dla socjologii (Lepenis 1996: 59). Aby umocnić swoją wyższą pozycję, socjologia zbliżyła się do nauk przyrodniczych, poszukując $w$ nich legitymizacji, jednocześnie silnie oddzielając się od literatury i sztuki, odgradzając rozum od uczuć. Ale nawet wtedy pojawiały się co jakiś czas głosy kwestionujące taką linię podziału, czego dowodzą prace Matthew Arnolda, Thomasa Stearnsa Eliota (Lepenis 1996), Gabriela Tarda, Franka Parkina (Watson 2016) czy eseje Clifforda Geertza (2005). I nawet gdy demarkacja została wytyczona $\mathrm{w}$ procesie społecznego konstruowania dziedzin wiedzy, była ona świadomie przekraczana przez wielu badaczy.

Zatarcie granic między literaturą a etnografią ma długie tradycje w antropologii. W 1916 roku Maria Czaplicka opublikowała Mój rok na Syberii [wyd. pol. 2013], jedną z pierwszych „konfesyjnych opowieści z pola badań", w 1954 wyszła antropologiczna powieść Return to Laughter, napisana przez Laurę Bohannan pod pseudonimem artystycznym Elenore Smith Bowen. Na początku XX wieku Bronisław Malinowski napisał Dziennik oraz Argonautów, które przypominają w stylu etnograficznej kreacji Jądro ciemności Josepha Conrada, którego Malinowski znał i czytał (Clifford 2000). W drugiej połowie ubiegłego wieku coraz częściej pojawiają się prace etnograficzne pisane w literackim stylu autobiografii, opowiadające o życiu i pracy badacza w terenie, które obecnie można zaliczyć do prac autoetnograficznych (por. Bielecka-Prus 2018). Po postmodernistycznym zwrocie w antropologii i krytyce obecności autora forma dialogiczna zaczęła coraz śmielej pojawiać się $\mathrm{w}$ tekstach antropologicznych (np. Stoller, Olkes 1987), gdyż dialog lepiej oddaje niedomknięcia i niejednoznaczność antropologicznego poznania, wielość punktów widzenia i ich niespójność. Badacz przestaje być dominującym głosem, traci swoją centralną pozycję na rzecz uczestników badania, którzy „przemawiają w swoim imieniu” (Mulkay 1985: 208). Ukazują się teksty pozbawione odautorskiego komentarza (np. Shostak 1981), towarzyszą innym danym zebranym $\mathrm{w}$ projektach partycypacyjnych przez autora/uczestników badania (np. zdjęcia, wy- 
kresy, fragmenty tekstów medialnych). Pisarze dokumentaliści z kolei systematycznie zbierają dane do swych książek, a efekty ich pracy coraz bardziej przypominają prace etnografów. Wśród współczesnych twórców, których pracom towarzyszyły badania, można wymienić Trumana Capote, Nadine Gordimer czy Swiatłanę Aleksijewicz.

Innym przykładem, z dziedziny nauk medycznych, może być książka angielskiego neurologa Oliviera Sacksa pod tytułem Mężczyzna, który pomylit swoja żone z kapeluszem (wyd. pol. 1996), w której autor opisuje w sfabularyzowanej formie sytuację życiową swoich pacjentów, którzy zmagali się z bardzo uciążliwymi chorobami neurologicznymi. Sacks (1996: 14) twierdzi, że patografia medyczna pozbawia pacjentów osobowości, sprowadza ich jedynie do przypadków chorobowych, dlatego też "chcąc znów umieścić cierpiący, zraniony, walczący ludzki podmiot w centrum uwagi, musimy pogłębić historię przypadku, zamienić ją na opowieść". A zatem badacze, nawet tak silnie osadzonych w pozytywizmie nauk jak medycyna, dostrzegają potrzebę wyjścia poza uprawiany paradygmat $\mathrm{w}$ poszukiwaniu innych dróg opisu rzeczywistości. Do takich eksploracji zachęcał William James (1904), głosząc konieczność poszukiwania takich form reprezentacji życia ludzkiego, które będą mogły uchwycić jego płynność, złożoność i niepowtarzalność. Sztuka mogłaby w tym dążeniu być przydatnym medium, wciąż jednak w dyskursie naukowym niedocenianym, a nawet traktowanym z lekceważeniem.

Zatarcie granic między nauką a sztuką związane jest także ze „zmąceniem gatunków” (Geertz 1990). Nowe formy pisania etnografii obejmuja teksty, które gatunkowo zbliżają się do literatury, a granica między tym, co faktualne z tym, co fikcyjne jest zatarta. Zacieranie fikcji i rzeczywistości, dzienni- karstwa i badań etnograficznych pojawiło się w tak zwanym „nowym dziennikarstwie”. Tworzone $\mathrm{w}$ tym nurcie teksty pozwalały autorom na wprowadzenie fikcyjnych zdarzeń czy postaci, aby wzmocnić moc ewokacyjną tekstu i odsłonić społeczne procesy konstruowania faktualności, odsłaniając autora tekstu i jego osadzenie w zróżnicowanych sytuacjach społecznych (Frus 1994). Zakwestionowano oczywistość podziału na literaturę fikcji i literaturę faktu (nonfiction), wskazując na istnienie gatunków mieszanych, takich jak powieść nonfaction, faction (powstała z połączenia słów fact i fiction, czyli „prawdziwa fikcja”), etnodramy, etnopoetyka, fikcja etnograficzna, dokument fabularyzowany (docudrama) i wszystkie inne wytwory „oparte na faktach”.

I choć granice między nauką a literaturą zacierały się, inne typy działalności artystycznej wciąż były traktowane z podejrzliwością. Nieco lepszą sytuację miały działania artystyczne oparte na sztukach wizualnych (fotografia, film etnograficzny), które dużo wcześniej ugruntowały sobie pozycję $\mathrm{w}$ socjologii czy antropologii (zob. Chaplin 1994). W przypadku sztuki literackiej sytuacja zaczęła się zmieniać dopiero w ostatnich dwudziestu latach. Pierwszy instytut badań opartych na sztuce założono w 1993 roku w Stanford University dla naukowców zajmujących się przede wszystkim badaniami edukacyjnymi. Elliot Eisner, twórca instytutu, zakładał, że sztuka może pomóc w rozumieniu problemów dydaktycznych i emocjonalnych pojawiających się $\mathrm{w}$ procesie uczenia się. Początkowo stanowiła jedynie działania wspomagające typowe badania społeczne (Eisner 2006). Obecnie pojawia się coraz więcej publikacji opartych o ABR, i to nie tylko w czasopismach poświęconych badaniom jakościowym (np. Qualitative Inquery, Forum: Qualitative Social Research, The Qualitative Report, Qualitative Social Research), ale także w pismach poświęconych na przykład edukacji czy 
zdrowiu (np. Educational Researcher, Medical Education, Journal of Aesthetic Education, Journal of Health Psychology). Ukazują się książki omawiające metodologiczne problemy ABR (np. McNiff 1998; Irwin, de Cosson 2004; Cahnamann-Taylor, Siegesmund 2008; Barone, Eisner 2012; Leavy 2015 [wyd. pol. 2018]), a także publikacje w całości poświęcone określonej dziedzinie twórczości, na przykład poezji (np. Prendergast $i$ in. 2009), sztukom performatywnym (np. Saldaña 2005), muzyce (np. Daykin 2004), tańcu (Bagley, Cancienne 2002). Prowadzone są kursy na studiach, głównie w USA, Kanadzie, Australii i Skandynawii, zarówno w dziedzinie nauk społecznych, terapii i nauk o zdrowiu, jak i artystycznych.

Prace metodologiczne dotyczące ABR są szczególnie cenne, gdyż porządkują terminologię i coraz bujniej rozwijające się procedury badawcze. Nadal jednak na tym polu jest dużo do zrobienia, co nie jest niczym niezwykłym, jeśli weźmiemy pod uwagę fakt, że ABR jest stosunkowo młodą perspektywą badawczą. Te same terminy stosowane są na nazywanie odmiennych aktywności badawczych - i odwrotnie - badacze tworzą własne nazwy dla tych samych desygnatów. ABR prowadzi się pod różnymi szyldami terminologicznymi. Patricia Leavy (2018: 48-49) wymienia niemal 30 nazw, wśród nich: „badania oparte na sztuce”, ,badania oparte na estetyce”, "alternatywne formy reprezentacji”, "sztuka w badaniach jakościowych", „badania zorientowane na sztukę", „żywe poszukiwanie”, „sztuka oparta na badaniach". W literaturze anglojęzycznej pojawiają się także inne terminy: „,a/r/tography" (Irwin, de Cosson 2004), "action-based inquiry” (Reason, Lincoln 1996). Każda z tych nazw zwraca uwage na inny aspekt procesu badawczego, odmiennie także waży rolę sztuki w badaniach. Na przykład termin „,a/r/togrography” pojawia się $\mathrm{w}$ działaniach dydaktycznych i wskazuje na wielość ról, jakie peł- ni badacz w procesie zbierania i analizy danych: artysty (artist), badacza (researcher) i nauczyciela (teacher) (Irwin, Springgay 2008). Pojawia się także zapis bez ukośnika, aby podkreślić holizm działań i ról (Gouzouasis 2013) lub zastępowany jest nazwą „Sztuka w procesie badań edukacyjnych" (arts-based educational research) (Piantanida, McMahon, Garman 2003). Projekty te tworzone są na przecięciu trzech obszarów działania: sztuki, edukacji i badań. Ten aspekt $A B R$ ceniony jest przede wszystkim przez osoby zajmujące się edukacją, które w procesie nauczania wykorzystuja działania artystyczne nie tylko do pogłębiania wiedzy i wrażliwości emocjonalnej uczniów, ale także aby poszerzyć swoją wiedzę o procesach poznawczych i dydaktycznych. Artografia jest szczególnie przydatna dla nauczycieli przedmiotów artystycznych, którzy mogą wykorzystywać ABR w procesie dydaktycznym, analizując proces tworzenia projektów artystycznych przez uczniów (Piantanida, McMahon, Garman 2003). Z kolei „action-based inquiry” łączy działania artystyczne $\mathrm{z}$ badaniami w działaniu, których głównym celem jest wprowadzenie pożądanych zmian społecznych, dlatego też wykorzystywane jest przez animatorów społecznych i organizacje pozarządowe.

W polskojęzycznej literaturze przedmiotu można spotkać następujące propozycje przekładu terminu art-based research: praktyki badawcze oparte na sztuce (Leavy 2018), badania posługujące się sztuką (Finley 2009; Pryszmont-Ciesielska 2015). Jednakże polska terminologia obarczona jest pewnym niedostatkiem semantycznym, gdyż traktuje sztukę jako dziedzinę pomocniczą, służebną wręcz, a ponadto zbytnio eksponuje podział na działania artystyczne i poznawcze. Dlatego w dalszym ciągu tego tekstu będę posługiwała się terminem „działania artystyczne w procesie badawczym” lub „sztuka 
w działaniach badawczych", który w bardziej wyraźny sposób wskazuje na integralność obu typów działań, lub skrótem ABR. W działaniach artystycznych $\mathrm{w}$ procesie badawczym te odrębne dziedziny twórczości człowieka zostają zatarte, sztuka i nauka splatają się ze sobą tak silnie, że nie można ich oddzielić: badanie może pojawić się na każdym etapie kreowania projektu artystycznego, podobnie jak artystyczne projekty mogą wspomagać proces badawczy na wszystkich jego etapach.

Analizując powiązania, jakie zachodzą między badaniami naukowymi a sztuką (np. Irwin 2004), często przywołuje się do Arystotelesowski podział czynności poznawczych na theoria (działanie nakierowane na prawdę), praksis (działanie nakierowane na dobro) i poiesis (działanie nakierowane na piękno). Sztuka jako jedna z form poznania, „wykracza poza czyste dane i sięga do poznania, dlaczego tak jest, albo do takiego poznania się zbliża i jako taka stanowi formę poznania" (Reale 1997: 568). Poznanie pojetyczne korzysta $\mathrm{z}$ danych uzyskanych $\mathrm{w}$ poznaniu informacyjnym (theoria), aby wytworzyć nowy przedmiot, wykorzystując wiedzę, która umożliwi wcielenie idei w materię (techne) (Krąpiec 1979). Jest to wiedza produktywna, która polega na umiejętności łączenia różnych elementów w całość tak, aby tworzyły obiekt funkcjonalny (na przykład krzesło) lub estetyczny (na przykład rzeźba). Aby takie obiekty tworzyć, niezbędna jest zarówno wiedza praktyczna, jak i teoretyczna. Grecka techne i łacińska ars oznaczały wszelką umiejętność wykonywania rzeczy zgodnie z przyjętymi regułami, były zatem działaniem racjonalnym i metodycznym (Tatarkiewicz 1970). Podobnie sprawa się ma zbadaniami inspirowanymi sztuką, które nie tylko są wiedzotwórcze, ale także nakierowane na praktyczne cele działań badawczych, wymagają także od badaczy umiejętności tworzenia estetycznych form, które budowane są na podstawie uzyskanej w badaniach wiedzy. Sztuka i nauka zbliżają się do siebie zwłaszcza wtedy, gdy tworzą dzieło poruszające uczucia i wyobraźnię, wzruszające i skłaniające do czynienia dobra, harmonijne i spójne w formie (Barone, Eisner 2012).

\section{Funkcje działań artystycznych w procesie badawczym}

Jednym ze sposobów uprawomocnienia działań artystycznych w procesie badawczym jest wskazanie ich szczególnych funkcji. Marian Golka (2008) wyróżnia kilka funkcji sztuki: estetyczną (zaspokaja potrzebę obcowania z pięknem), hedonistyczną (sprawa przyjemność), poznawczą (przekazuje wiedzę o świecie), ekspresyjną (wyraża przeżycia twórcy), komunikacyjną (tworzy płaszczyznę porozumienia), ideologiczną (krytyka społeczna), terapeutyczną (działa katartycznie i dezalienacyjnie) i wychowawczą (uczy, jak postępować). W ABR wszystkie te funkcje pojawiają się, ale szczególną wartość mają ostatnie z pięciu wymienionych. Działania artystyczne mogą być środkiem perswazji społecznej, drogą do samopoznania i terapii, pomocą dydaktyczną w edukacji, a także pomocą w tworzeniu nowej wiedzy i jej reprezentacji (Piantanida, McMahon, Garman 2003).

Celem ABR, podobnie jak i sztuki, jest tworzenie projektów, które mają przekazywać określoną wiedzę o świecie i wewnętrznych przeżyciach innych. Doświadczenie jest kluczowym pojęciem wyznaczającym perspektywę metodologiczną. Nie jest ono jedynie procesem kognitywnym, ale odnosi się do działającej istoty ludzkiej, zaangażowanej w świat emocjonalnie i cieleśnie. Przejawami doświadczenia są zmaterializowane $\mathrm{w}$ formie wytworów ekspresje, także artystyczne (Bruner 2011). 
Środki ekspresji artystycznej są w stanie wyrazić uczucia, które następnie można poddać kontemplacji (Tuan 1987). O świecie i nas samych można opowiadać, używając różnych sposobów reprezentowania, język naturalny nie jest jedynym narzędziem, jakim człowiek dysponuje. Jeśli założymy, że różne kategorie symbolicznych narzędzi, którymi się posługujemy, otwierają różne przestrzenie poznawcze, inne wymiary rzeczywistości, to słuszna wydaje się teza, że warto wykorzystywać multimodalność metod w działaniach poznawczych. Dlatego też sztuka, która wykorzystuje pozawerbalne środki ekspresji, pozwala zobaczyć nam to, co jest ukryte przed nami, gdy używamy klasycznych metod poznawczych, tak jak użycie mikroskopu skłania nas do innych pytań, niż użycie teleskopu (Eisner 1997).

Działania artystyczne pełnią w procesie badawczym szczególną funkcję, gdyż nie dążą do budowania teorii szerokiego zasięgu, generalizowania wniosków na szersze zbiorowości społeczne, ugruntowania teorii w danych czy ich testowania. Skupiają się na dokumentowaniu złożoności życia ludzkiego w różnorodnych kontekstach, ukazują głębię i niepowtarzalność doświadczeń jednostkowych. Nie poprzestają jednak jedynie na tym. Te silnie skontekstualizowane opisy jednostkowych przeżyć odnoszą się także do wzorów i praktyk społecznych, prawidłowości życia zbiorowego, są artystycznie wyrażonymi studiami przypadków, w których problemy makrospołeczne znajdują swoje inkarnacje ukryte w alegorycznej formie, łączącej globalne procesy społeczne z lokalnymi działaniami jednostek (Watson 2016). „Sztuka nie jest sposobem wydobycia opornych prawd i umieszczenia ich na wystawce jak na tacy - gotowych do zjedzenia. W najlepszym wypadku może nam coś pokazać - a nie opowiedzieć o tym, co to znaczy być istotą ludzką" (Tamas
2008: 20 [tłum. własne]). Sztuka opowiada o świecie poprzez idiosynkrazję, a nie generalizację. Znacznie ważniejsze jest strukturalne wzmocnienie (structural corroboration) naszej wiedzy o rzeczywistości poprzez coraz bardziej wieloaspektowe jej opisy. Nie chodzi zatem o uzyskanie jednego obrazu rzeczywistości, lecz przeciwnie: namnażanie ich, aby owocowały w coraz pełniejszym, jak by napisał Clifford Geertz (2005), bardziej „zagęszczonym” opisie świata (thick description). Obrazy te nie ulegają rozproszeniu, bowiem w procesie poznawczym ważna jest także konsensualna walidacja (consensual validation), która polega na poszukiwaniu zgodnych punków widzenia, podobnych interpretacji, które budują intersubiektywną płaszczyznę podzielanej społecznie wiedzy (Eisner 2006).

Najwięcej sporów budzi kwestia referencyjności działań artystycznych, ich odniesienia do badanej rzeczywistości społecznej. Zarzuca się twórcom ABR skrajny subiektywizm. Zwolennicy bronią się tym, że ten problem dotyczy wszystkich badań jakościowych, gdyż w badaniach nigdy nie mamy do czynienia $\mathrm{z}$ „,surowymi” danymi. Już na poziomie zbierania są one konstrukcją drugiego rzędu, która w procesie badawczym podlega daleko idącej interpretacji, kolejnym rekonstrukcjom i przekształceniom, aż do ostatecznego wytworu, zwykle w postaci przyjętych w nauce gatunków: wykładu, raportu, artykułu lub monografii. Dlatego też narracje, które powstały na podstawie badań terenowych, nie są jedyną możliwą wersją zdarzeń. Podobnie jest w przypadku działań artystycznych, jednakże selekcja jest tu daleko bardziej refleksyjna, gdyż badacze nie próbują ukryć się za parawanem obiektywności. Zarówno proces badawczy, jak i jego artystyczna reprezentacja jest jednym z wielu możliwych sposobów selekcjonowania i interpretowania danych. Badacz, podobnie 
jak artysta, w sposób jawny jest kreatywny i aktywny w procesie badawczym, świadomy swojej roli, działań i wpływu, jaki wywiera na otoczenie społeczne oraz tworzone artefakty. W przypadku ABR można mówić o dwóch typach refleksyjności, które mogą się pojawić w tym samym wytworze. Pierwszy typ to refleksyjność konfesyjna, która przybiera formę autoetnografii, drugi zaś, proponowany przez Pierre'a Bourdieu i Loïca Wacquanta epistemologiczny namysł nad procesem tworzenia wiedzy (Denzin 2003). Nie bez znaczenia jest także powiązana z refleksją funkcja terapeutyczna, zwłaszcza dla osób przeżywających traumę, bo daje możliwości głębokiego przepracowania doświadczeń, ekspresji stłumionych przeżyć prowadzącej do catharsis. Pisanie może być formą terapii, w której podejmujemy dialog z samym sobą.

W kwestii referencyjności ABR krytykuje się także za to, że projekty artystyczne są fikcyjne, nie opisują rzeczywistości. Norman Denzin (2003), krytykując ujęcie fikcji jako fantastyki czy iluzji, przywołuje etymologię słowa "fikcja” (fictio), które pierwotnie odnosiło się do wszelkiej działalności twórczej: „nie chodzi o to, że są to rzeczy fałszywe, nie oparte na faktach czy będące jedynie wydumanymi eksperymentami myślowymi" (Geertz 2005: 30). Fikcja tworzona jest $\mathrm{w}$ procesie selekcji określonych elementów rzeczywistości empirycznej i łączenia ich w całość. Przywołując Geertza, Denzin dowodzi, że niesłuszne jest przeciwstawianie tego, co faktyczne temu, co fikcyjne, gdyż powieści literackie, podobnie jak raporty badawcze $\mathrm{w}$ naukach społecznych wychodzą od danych z rzeczywistego świata, aby potem ulec twórczemu przekształceniu. Taka silna demarkacja między faktem a fikcją wynika z lęku badaczy życia społecznego przed posądzeniem o „nienaukowość”, co wiąże się z dyskredytacją ich pozycji na polu pozytywistycznie ujętej wie- dzy pewnej. W tradycyjnych raportach buduje się ją wokół tezy, która ma być udowodniona, w sztuce zaś elementy te, łączone w określonej konfiguracji, tworzą pewną znaczącą całość, która daje wgląd wrealną rzeczywistość. W obu przypadkach wiedza o tym, co istnieje realnie wiedzie przez fikcyjne artefakty. $\mathrm{O}$ tym, czy dany tekst jest fikcją, decyduje jego samo-ujawnienie (self-disclosure), czyli obecność silnie skontekstualizowanych kulturowo i historycznie wskazówek, czy dane dzieło traktować jak literacką imaginację (Iser 1993: 16-17 za: Denzin 2003: 104). Według Saldañy (2005) nie jest istotne, czy sztuka jak najwierniej odtwarza zdarzenia, ma ona być prawdopodobna (verisimilitude) i uniwersalna, to znaczy taka, aby jej symbolika odnosiła się do wielu innych realnych zdarzeń.

Granica między faktem a fikcją w paradygmacie konstruktywistycznym jest kwestią niepewną isporną, a „fikcjonalizacja nie oznacza odejścia od autentyczności, przeciwnie: może wzmacniać prawdziwość badania (truthfulness)" (Ackroyd, O’Toole 2010: 64 [tłum. własne]). Pisanie o fikcyjnej osobie pozwala na oddalenie się od lokalnego kontekstu własnych przeżyć, nabranie dystansu do własnej kultury, de-normalizację praktyk społecznych (Brennan 1993). A zatem projekty artystyczne są istotnym źródłem wiedzy o świecie, choć opowiadają o świecie fikcyjnym. Jak zauważył Wiktor Szkłowski (1986), wybitny formalista rosyjski, celem sztuki jest defamiliaryzacja, która sprawia, że rzeczy postrzegane do tej pory jako dobrze znajome stają się niezwykłe i obce, a dzięki temu poszerzają się granice ludzkiej percepcji. Zmiana struktury obiektu, jego formy, wielkości, koloru czy pozycji wkontekście innych obiektów podważa dominujące reżimy postrzegania i zaczarowuje świat na nowo. Mają temu służyć artystyczne chwyty: unikanie nazywania obiektów wprost, poetyzacja ję- 
zyka, zaburzenie porządku irytmu procesów, operowanie paradoksem (Lawrence-Lightfoot 2005). Techniki te skłaniają odbiorcę do nowego spojrzenia na znane mu sprawy i uzyskanie przez to dystansu do nich. Są pomocne w kreowaniu nowych pojęć, mogą katalizować nowe pytania badawcze, pomagają przeformułować lub doprecyzowywać stare, ująć zjawisko z zupełniej nowej perspektywy. Metafory i nasycenie symboliką pozwalają na uchwycenie znaczeń, które bardzo trudno poddają się ekspresji dyskursywnej, na przykład emocji i wrażeń sensorycznych (Barone, Eisner 2012). Dlatego też metody te świetnie nadają się do badania różnego rodzaju działań trudno poddających się dyskursywizacji (np. procesy twórcze). Lewis Coser (1963) wykorzystywał teksty literackie do nauczania socjologii, gdyż były one doskonałym źródłem wiedzy o społeczeństwie, ale także świetną pomocą dydaktyczną $\mathrm{w}$ analizie zjawisk społecznych (Watson 2016).

ABR może także pełnić funkcję prognostyczną, bowiem czasem zdarza się, że dzieła artystyczne kryją $\mathrm{w}$ sobie zalążki idei, rozwijanych potem $\mathrm{w}$ innych dziedzinach twórczości, na przykład w nauce czy w architekturze (Golka 2008; Bonenberg 2013). Artyści to ludzie często obdarzeni wyobraźnią współczującą (Szpunar 2018), wrażliwi na dysonanse, niespójności czy nieprzystawalności światów lub ich reprezentacji, zdolni do tworzenia futurologicznych wizji (Golka 1995, dlatego też literatura czy sztuka może wyprzedzać naukowe opisy rzeczywistości i antycypować przyszłe teorie (Benedyktowicz 1995).

W ABR nie chodzi jedynie o deskrypcje rzeczywistości czy raportowanie zdarzeń. Projekty przede wszystkim powinny pełnić funkcję ewokacyjną, która polega na wywoływaniu w odbiorcach wie- lorakich przeżyć, poprzez które odbiorca nie tylko ma wgląd w przeżycia innych ludzi i może w tych przeżyciach poprzez empatyczne rozumienie współuczestniczyć, ale także, jak twierdził Wilhelm Dilthey, przez wytwory ekspresji innych ludzi odbiorca może zrozumieć samego siebie i własne przeżycia (Bruner 2011). Działania artystyczne wprocesie badawczym są bogate $\mathrm{w}$ detale, silnie nacechowane emocjonalnie, dlatego w pogłębiony sposób ukazują procesy społeczne i transformacje tożsamości w retrospektywnym ujęciu (Bochner 2000). Na przykład etnodramy przygotowane na podstawie badań osób chorych na schizofrenię są źródłem nowej wiedzy dla lekarzy, a także dla studentów medycyny przygotowujących się do zawodu (Schneider 2005). Wytwory artystyczne są medium komunikacji miedzy badaczem a badanym, za Alfredem Gellem można je nazwać nexusem, który ma moc performatywną (Kawalec 2016). Tworzone projekty nie tylko przekazują znaczenia, ale są działaniem i skłaniają do działania, „mają pokazywać, a nie mówić" (Denzin 1997: 40), tworzą otwartą przestrzeń ekspresji i dialogu. „Wiemy, co się stało i możemy o tym opowiedzieć pełnymi zdaniami. Możemy opowiedzieć innym, nawet osobom całkiem obcym, prawdę o naszych doświadczeniach. Wydawać by się mogło, że znaleźliśmy sposób, jak zrobić ten iluzjonistyczny gest, stanąć na zewnątrz i ponad sobą, aby beznamiętnie opowiedzieć o swojej pasji. To tak właśnie trauma zmienia się w wiedzę" (Tamas 2008: 10 [tłum. własne]).

Sztuka w działaniach badawczych jest „formą kinetyczo-estetyczną" (Richardson, Lockridge 1998: 328 za Finley 2003), gdyż jej zadaniem jest poruszenie i zaangażowanie odbiorcy. To proces, który nie skupia uwagi badacza i odbiorcy na finalnym efekcie, zakończonym raporcie, ale na procesie tworzenia, jest otwarty na kolejne interpretacje, reformułowa- 
nie i poszerzanie przez dodawanie nowych tekstów. Autorzy mogą zostawić dzieło niedokończone lub pełne luk, aby odbiorcy mogli je wypełnić własną treścią, odnieść do własnych doświadczeń i problemów we własnym otoczeniu społecznym, w ten sposób silniej włączać odbiorców i wzmacniać moc performatywną projektu (Denzin 2003; Watson 2016). Eudora Welty (1983 za Lawrence-Lightfoot 2005) trafnie odróżniła słuchanie opowieści (listening to a story), w którym rola odbiorcy sprowadza się do pasywnego odbioru, od słuchania dla opowieści (listening for a story), gdzie odbiorca jest aktywny, nadaje kształt i spójność dziełu. ABR nie jest po to, aby coś udowadniać, dojść do konkluzji, ale żeby zrobić miejsce dla nowych otwartych pytań, które nie domagają się natychmiastowej odpowiedzi. Nie chodzi o przedstawienie "prawdziwej” wersji zdarzeń, ale stworzenie prawdopodobnej historii i zaproszenie do tworzenia kolejnych wersji, możliwych i niemożliwych (por. Bochner, Ellis 2003). W badaniu sam proces jest ważniejszy niż rezultat, co otwiera płaszczyznę dialogu między badaczem a uczestnikami badania oraz odbiorcami. Warto zwrócić uwagę na to, że role te nie są od siebie wyraźnie oddzielone. Scenariusz sztuki powstaje zwykle przy współudziale osób, z którymi przeprowadzano wywiady, jak było to na przykład $\mathrm{w}$ etnodramie o kobietach walczących $\mathrm{z}$ rakiem piersi (Gray i in. 2000). Zaangażowanie badanych $\mathrm{w}$ proces tworzenia projektu ma istotne funkcje. Pozycje uczestników nie są zhierarchizowane, gdyż badacze nie zajmują dominującej roli, opowiadają z badanymi, a nie o badanych, a selekcja fragmentów wywiadów i ich interpretacja staje się bardziej wiarygodna i rzetelna.

ABR pełni także funkcję emancypacyjną. Sztuka w działaniach badawczych ma na celu podważanie rozpowszechnionych stereotypów, które repro- dukują niesprawiedliwości społeczne i zamykają umysły ludzi w wąskich klatkach. Projekty podważają powszechnie uznawane sądy, konwencjonalne sposoby ujmowania świata, zachęcając odbiorców do ich rewizji, wprowadzając elementy dyslokacji, niepokoju poznawczego, nieciągłości i zakłócenia (Barone, Eisner 2012). Bardzo wyraźnie ujawnia się wpływ teorii krytycznej na ABR. Tworzone projekty często podważają dominujące narracje, kwestionują słuszność i legitymizację istniejących hegemonii. Dążą do wywołania pozytywnych zmian społecznych poprzez wpływanie na postawy odbiorców, ich sposoby doświadczania świata, a nawet prowadzą do epifanii i zmiany projektów życiowych. Podejście krytyczne polega nie tylko na umiejętności krytycznego myślenia opartego na socjologicznej wyobraźni, ale także na zdolności wyzwolenia się z opresyjnych struktur, rozwijaniu samoświadomości i refleksyjności, które pomagają stwarzać nowe, lepsze światy. Na przykład Teatr Uciśnionych Augusto Boala miał za zadanie upełnomocnienie grup wykluczonych, ale także walkę o nowy, sprawiedliwy ład społeczny. Postuluje się, aby badania były "radykalną etyczną estetyką" (Denzin 2003: 261) zaangażowaną w walkę przeciwko represyjnym strukturom reprodukowanym w codziennych interakcjach.

Inną bardzo ważną zaletą $A B R$ jest otwartość i egalitaryzm. Dlatego też $\mathrm{w}$ projektach $\mathrm{ABR}$ bardzo często biorą udział przedstawiciele grup zmarginalizowanych, których głos nie jest słyszalny we wrzawie publicznego dyskursu. Na przykład Jim Mienczakowski (2001) wraz ze współpracownikami przygotowywał etnodramy o osobach chorych na schizofrenię, uzależnionych od substancji psychoaktywnych i osobach, które doświadczyły napaści seksualnej, a Saldaña i jego zespół badawczy zrobili etnodramę „Street Rat” o osobach bezdomnych. 
Formy artystyczne bardzo dobrze sprawdzają się w badaniach partycypacyjnych, w których zakłada się symetrię relacji między badanymi a badaczami czy, jak postuluje teoria krytyczna, drugoosobową perspektywę badawczą (Bryda, Martini 2016). Co więcej, ABR włączają do procesu badawczego odbiorców, zapraszając do debaty nad wytworzonymi reprezentacjami i problemami. Wspólne tworzenie, przeżywanie i przekształcanie dzieł tworzy wspólnotę działania, poprzez którą badacz może zbliżyć się jeszcze bardziej do świata przeżywanego badanych (Finley 2003). Zwolennicy radykalnego podejścia do partycypacji uważają, że badani powinni się sami wypowiadać o swoich problemach, a badacz pełni jedynie funkcję moderatora, a nie autora projektu (Barone, Eisler 2012). Projekty badawcze nie są tworzone jedynie dla wąskiego grona naukowców, ale dla wszystkich członków społeczności. Nauka nie jest już dłużej zamknięta w wieży z kości słoniowej, ale staje się udziałem wielu osób spoza akademickiego świata. Bardzo ważnym zadaniem badań angażujących sztukę jest dotarcie do szerokiej grupy odbiorców, dlatego też rezultaty takich projektów badawczych można zobaczyć nie tylko na konferencjach naukowych (może tam właśnie najrzadziej), ale przede wszystkim $\mathrm{w}$ przestrzeni publicznej: teatrach, przestrzeni miejskiej, szkołach, szpitalach, a także w przestrzeni wirtualnej, na przykład w mediach społecznościowych.

\section{Jakość w ABR}

ABR nie rości sobie prawa do zastąpienia tradycyjnych metod jakościowych, przeciwnie: są one intensywnie wykorzystywane przez badaczy (np. wywiady, obserwacje) i uzupełnianie innymi źródłami wiedzy, aby poszerzyć zakres oglądu świata społecznego i zwiększyć „epistemologiczną różnorodność" (Barone, Eisner 2012), a także realizować zadania wyznaczone przez socjologię publiczną (public sociology) (Burawoy 2005; Watson 2016). Sztuka nie jest traktowana jako dzieło, ale jako doświadczenie, które może być wyrażone wróżnorodnych formach werbalnych, wizualnych, ruchowych, które nie tworzą zamkniętej listy. Możliwe jest eksperymentowanie $\mathrm{z}$ nowymi środkami ekspresji oraz łączenie wielu form $\mathrm{w}$ zintegrowane projekty badawcze (Barone, Eisner 2012). Przeprowadzona przez Grzegorza Brydę i Natalię Martini (2016) analiza słownikowa publikacji w czołowych periodykach z obszaru badań jakościowych, które ukazały się w latach 2002-2015, pokazała, że w ramach ABR można wyróżnić 28 metod, między innymi: kolaż, taniec, udramatyzowany tekst, rysunek, etnodramę, film, powieść, performans, opowieść, opowiadanie. Gatunki te w ramach jednego projektu moga być mieszane ze sobą, łączy się także sztuki werbalne, wizualne, audialne, performatywne. Wykorzystuje są także teksty z obszaru dyskursu publicznego. Na przykład Maria K. E. Lahman (2011) zebrała teksty z artykułów prasowych, blogów, komentarzy, aby skomponować z nich wiersz o zamordowanej w okrutny sposób transseksualistce. Metodę tę nazwała poezją archiwalną lub artifaktem. Autorzy mogą celowo wybierać formy zapisu, które będą silnie osadzone $\mathrm{w}$ badanej kulturze. Brian Moeran (1996), który analizował japońską kulturę, swoje notatki terenowe przekształcił w fikcyjny dziennik inspirowany stylem nikki przeplatanym z haiku.

Nie ma prostych recept, które wskazywałyby, w jaki sposób postępować w tworzeniu projektów badawczych wykorzystujących sztukę, gdyż w dużej mierze, znacznie bardziej niż inne metody jakościowe, opierają się one na improwizacji (Clough 2000; Lawrence-Lightfoot 2005). Podstawowe pytania, jakie należy zadać przed rozpoczęciem projektu $A B R$, to: jaki jest cel projektu i jaką funkcję w tym projekcie 
ma pełnić sztuka. Dobry projekt powinien rodzić nowe pytania i nowe idee, a nie jedynie odpowiadać na te, które były już postawione (Eisner 2006). Powinien być cenny poznawczo, ale także dobrze napisany: $\mathrm{z}$ interesującą fabułą, dobrze nakreślonymi postaciami i żywymi dialogami uwzględniającymi dialog wewnętrzny. Ważne jest, aby projekt umożliwiał wielowymiarowe interpretacje, na przykład tworząc luki w tekście, które mogą być wypełniane przez odbiorców i budować dialektyczne napięcia $\mathrm{w}$ fabule (Denzin 2003). Eksperymentuje się z formą: na przykład tekst może być podzielony na kilka kolumn, wykorzystuje się spacje między wierszami, nadaje się mu nielinearną formę, aby czytelnik samodzielnie spajał tekst w całość (wzorem Gry w klasy Julio Cortázara), zrywa się z zasadą jedności czasu, miejsca i akcji, burząc porządek przyczynowy zdarzeń, aby odbiorca mógł skonstruować wiele możliwych interpretacji, dopuszcza się do głosu wielu aktorów społecznych, a badacz przestaje pełnić dominującą rolę jedynie słyszalnego eksperta. Saldaña (2005) zaleca także napisanie narracji z perspektywy różnych uczestników konfliktu, aby jak najgłębiej zrozumieć różne punkty widzenia jednostek. Często nie mamy do czynienia (jak np. $\mathrm{w}$ performansie) $\mathrm{z}$ jednym tekstem, ale $\mathrm{z}$ układem wielu powiązanych ze sobą tekstów, które ewoluują $\mathrm{w}$ procesie konstruowania występu, pracy scenicznej, a potem także w wyniku ponownego przepracowania tekstu z odbiorcami sztuki.

W ABR nie ma jednej metodologii analizy zebranych danych, można stosować bardzo zróżnicowane metody i łączyć je ze sobą. Zwykle pracuje się na danych zakodowanych, choć nie jest konieczne tworzenie gęstej siatki kodów. Można kodować dane według kluczy opracowanych przez innych badaczy, na przykład posługując się listą „rodzin kodowania” zalecaną przez Barneya Glasera (1978), do której należą: przyczyny, konteksty, możliwe przebiegi działań, konsekwencje, kowariancje i warunki, a w przypadku zjawisk procesualnych: stadia, staw nie się, fazy, fazowanie, postępy, przejścia, gradacja, rangi, kariery, trajektorie, łańcuchy, sekwencje, czasowość, cykliczność, kształtowanie, porządkowanie (Konecki 2008). Można także skupić się na zwrotach najczęściej pojawiających się lub niosących największy ładunek ekspresji lub zastosować kategorie zaproponowane przez Saldañę (2009): cele, konflikt pojawiający się $\mathrm{w}$ realizacji, taktyki, które pozwalają na osiąganie celów, postawy, ukryte znaczenia i emocje. Sztuka jest źródłem wiedzy, ale także formą ekspresji zebranych danych. Wytworzone teksty mogą być prezentowane odbiorcom $\mathrm{w}$ różnorodny sposób: mogą być odgrywane przez autora/autorów tekstu, uczestników badania, osoby trzecie, a także publikowane w formie tekstowej lub/i audio/wizualnej. Formy te mogą być łączone w jednym projekcie, na przykład autorzy moga przygotować fragmenty testów rozdawane podczas spotkania i zachęcać do odegrania lub odczytania określonego fragmentu (Denzin 2003). Wytworzone teksty mogą być punktem wyjścia do kolejnych działań badawczych, podstawą do tworzenia kolejnych artefaktów lub przekształcania już istniejących (Finley 2003).

Nie jest łatwe sformułowanie kryteriów, które pozwalają ocenić jakość badań opartych na sztuce. ABR są otwarte na wszelkie przejawy twórczości, szczególnie te niesakralizowane, heterodoksyjne, niekonwencjonalne. Dlatego też niektórzy z badaczy z powściągliwością gotowi są stosować do wytworzonych w ramach ABR artefaktów podobne kryteria oceny jak te, które obowiązują w sztuce (Finley 2003). Uważają oni, że nie ma sensu tworzyć listy takich kryteriów, a nawet więcej - są przeciwni włączaniu tego typu działań do pola 
nauki i twierdzą, że tworzą one odrębny paradygmat, nie będąc ani nauką, ani sztuką (np. Eisner 1981). Pojawiają się obawy, że wyznaczanie kryteriów ograniczy odważny krytycyzm kulturowy i doprowadzi do ortodoksji, dlatego należy je ograniczyć do niezbędnego minimum (Clough 2000). Inni badacze uważają, że trzeba opracować jakieś bardziej szczegółowe wskazówki. Przekonują, że są one pomocne dla samych badaczy, ale także dla sceptyków, którzy wykluczają tego typu działania z pola badań właśnie ze względu na brak reguł ich tworzenia i ewaluacji. Tu także nie ma jednolitego stanowiska. Jedni uważają, że kryteria mogą być takie same jak w przypadku oceny dzieła artystycznego, gdyż badacz jest jednocześnie artystą (np. Finley 2003), inni zaś twierdzą, że należy opracować osobne wskazówki, które powinny być silnie skontekstualizowane, czyli powinny brać pod uwagę sytuację badawczą (Bochner 2000).

Większość badaczy zgadza się jednak, że dobry projekt powinien mieć odpowiednią formę ekspresji i spełniać wszystkie, lub przynajmniej większość, zomówionych powyżej funkcji. Projekt powinien być zwięzły, precyzyjny i oszczędny w formie. Przenikliwość, wnikliwość i wyrazistość (incisiveness) może być zawarta $w$ jednym zdaniu czy jednym obrazie (np. Eisner usłyszał takie zdanie od dyrektora szkoły: „Szkoła to miejsce, gdzie jest bardzo mało miękkich powierzchni"). Musi być poprzedzony wnikliwymi badaniami terenowymi, jednakże uzyskane dane powinny być bardzo starannie wyselekcjonowane i skondensowane, aby ich „esencja" mogła być wyrażona w kilkustronicowej narracji lub haiku. Inną ważną cechą jest koherencja, gdyż efekty pracy badawczej powinny być spójne, posiadać rdzeń spajający wątki czy problemy. Kolejne kryterium to generatywność, która zakłada, że dzięki sztuce odsłonią się te aspekty rzeczywisto- ści, które pozostawały w ukryciu, nie poddawały się praktykom dyskursywnym lub nie były ze sobą powiązane. Badania są wiarygodne i rzetelne, gdy wnioski z badań są silnie ugruntowane $\mathbf{w}$ danych i przekonujące, a przedstawiony materiał ewokuje kolejne pytania badawcze. Istotne jest zatem to, na ile badania okrywają obszary, które nie byłyby odsłonięte, gdyby badacz posługiwał się tradycyjnymi metodami. Kluczowe jest tu zatem pytanie: co więcej udało się zobaczyć, stosując metody wykorzystujące sztukę (Barone, Eisner 2012). Bardziej niż trafność ważna jest wiarygodność badań (credibility) oraz autentyczność. Podobnie jak w przypadku fikcji literackiej istotna jest prawdziwość w doświadczaniu, a nie prawdziwość z doświadczeniem (Denzin 2003).

Denzin (2003) proponuje, aby oceniając projekt badawczy, wziąć pod uwagę wymiar moralny, polityczny i etyczny oraz to, jak wymiary te są realizowane $\mathrm{w}$ ramach estetyki. Wskazuje na trzy kluczowe kryteria: 1. interpretacyjną samodzielność (sufficiency): projekt artystyczny powinien być głęboki, emocjonalny, nasycony szczegółami i koherentny; 2. reprezentacyjną adekwatność: powinien opowiadać o rzeczywistości w sposób pozbawiony stereotypów i hegemonicznych ideologii; 3. autentyczną adekwatność, uwzględniającą wielogłosowość i motywującą do społecznej transformacji. Lincoln (1995) dodaje do tej listy kolejne kryteria: 1. zaangażowana interakcja między badaczem a uczestnikami; 2. podjęcie działań, które mogą polepszyć życie uczestników; 3. praca nad zorientowaną na przyszłość społecznością, w której respektowane będą podstawowe normy i wartości życia społecznego: sprawiedliwość, szacunek dla drugiego człowieka bez względu na jego pozycję i przekonania, etyka troski. Standardy te moga być zrealizowane, jeśli 
a. pozycja autora w tekście będzie wyraźnie zaznaczona,

b. tekst adresowany będzie do ludzi, których badanie dotyczy,

c. dzieło angażuje i włącza ludzi, których głos jest słabo słyszalny w dyskursie publicznym,

d. bierze pod uwagę emocje i przeżycia autora przed, w trakcie i po badaniach, uwzględnia jego zaangażowanie i pozycję społeczną (warunek refleksyjności),

e. jest otwarte na współpracę i refleksyjną praktykę między autorami a uczestnikami.

Darquise Lafrenière i Susan M. Cox (2012) dokonały uporządkowania kryteriów oceny działań artystycznych $\mathrm{w}$ procesie badawczym. Według nich kryteria te można podzielić na normatywne i substantywne. Kryteria normatywne odnoszą się do zasad metodologicznych i etycznych stosowanych na wszystkich etapach procesu badawczego. Ocenia się zasadność zastosowanych metod i technik zbierania danych, stopień ich osadzenia w kontekście społecznym, rzetelność (np. stosowanie triangulacji) oraz poprawność metod analizy danych ispójność z postawionymi pytaniami badawczymi. Kwestie etyki biorą pod uwagę sposób, w jaki badacz uzyskał dostęp do danych, zachowanie zasady anonimowości, przestrzeganie reguły nieczynienia krzywdy i działania dla dobra badanych, sprawiedliwego przypisywania autorstwa wytwarzanym projektom i zapewnienie możliwości partycypacji badanych $\mathrm{w}$ procesie tworzenia dzieła i jego oceny. Kryteria substantywne zwracają uwagę na cechy artystyczne i techniczne artystycznego wytworu. Kluczowe są tutaj następujące wymogi: adekwatność środków ekspresji do podejmowanego tematu, dobra kompozycja dzieła, koherencja, kreatywność i oryginalność.

\section{Zakończenie}

Wprowadzenie projektów artystycznych do badań niesie ze korzyści zarówno dla badacza, badanych i szerszego grona odbiorców. Nie oznacza to jednak, że projekty realizowane $\mathrm{w}$ ramach $\mathrm{ABR}$ są łatwe i proste. Aby były jakościowo dobre, muszą sprostać zarówno wymaganiom stawianym badaniom jakościowych, jak i artystycznym. Dlatego też badacze, którzy zdecydują się na tego typu projekt, powinni być świadomi wielu trudności, z jakimi będą musieli się zmagać w terenie badawczym. Niektóre z nich pojawiają się także $\mathrm{w}$ innych badaniach jakościowych (np. wejście w teren, dotarcie do właściwych informatorów, nawiązanie relacji z badanymi i odźwiernymi itp.). Mogą się jednakże pojawić problemy specyficzne dla ABR, które naruszają jakość projektów artystycznych.

Fundamentalnym problemem jest miejsce działań artystycznych w procesie badawczym, ich autonomii lub zależności od celów badawczych. Stanowiska teoretyczne, głoszące „bezfunkcyjność” sztuki, autonomię i koniczność dystansu społecznego sprzeciwiają się instrumentalistycznemu traktowaniu sztuki w badaniach, które sprowadzają ją do roli metody (np. Theodor W. Adorno, por. Czekaj 2013). Jednakże takie stanowisko, zdaniem Artura Żmijewskiego, prowadzi do alienacji sztuki, dlatego instrumentalizacja autonomii mogłaby temu wyobcowaniu zapobiec. Artyści nie powinni się zatem obawiać ABR jako formy stosowanych sztuk społecznych (Żmijewski 2007).

Trudności mogą także pojawić się w realizacji wymogu partycypacji. Bardzo ważna jest etyka badań, która powinna opierać się na etyce troski i odpowiedzialności. Podważanie dominujących hegemonii 
nie może być realizowane za szelką cenę. Przeciwstawianie się dominującym dyskursom musi brać pod uwagę skutki takich działań dla interesariuszy, tak aby nie wywarły negatywnych efektów na uczestnikach projektu czy widzach. Badacz może niechętnie rezygnować z głosu eksperta i pozostawiać badanym zbyt mało miejsca na przedstawienie własnej perspektywy zdarzeń, badani zaś nie będą intensywnie angażować się w tworzenie projektu, gdyż nie widzą sensu takich działań lub nisko oceniają swoje kompetencje twórcze (por. Bielecka-Prus 2013).

Ponadto projekt może jedynie deklaratywnie podważać istniejące stosunki władzy, faktycznie zaś utrwalać te relacje w bardziej zamaskowanej formie, służąc dominującym ideologiom lub działając na zlecenie władzy, czerpiąc zyski w postaci grantów i budując pozycję na polu nauki lub polu organizacji pozarządowych. W badaniach partycypacyjnych trudniej także osiągnąć konsensus ze względu na mnogość pojawiających się schematów interpretacyjnych, które trzeba wykluczyć z projektu, aby nie stracił on czytelności dla odbiorcy. Można także powątpiewać, czy uda się całkowicie wyeliminować relacje władzy z procesu badawczego, odrzucić hegemoniczną lub ekspercką rolę badacza, który zajmuje uprzywilejowaną pozycję. Jeśli uznamy, że jest to utopia metodologiczna, to znacznie lepiej, jeśli badacz ujawni te relacje i podda je socjoanalizie (Barone, Eisner 2012). Mogą się także pojawić problemy związane

\section{Bibliografia}

Ackroyd Judith, O'Toole John (2010) Performing Research: Tensions, Triumphs and Trade-Offs of Ethnodrama. Stoke-on-Trent: Trentham Books.

Atkinson Paul (1992) Understanding Ethnographic Texts. London: Sage. z upowszechnianiem projektu. Język artystyczny może okazać się zbyt zawiły, niejasny i w związku z tym nieczytelny dla odbiorcy (Atkinson 1992). Aby tworzyć projekty artystyczne, trzeba mieć nie tylko pewną wiedzę i umiejętności, ale także talent i dobre pióro (Finley 2003). Badacze przywykli do sformalizowanego stylu pisania i naukowej nowomowy mogą czuć, że stąpają po bardzo śliskim gruncie. Dlatego też niektórzy zwolennicy ABR radzą, aby tworzyć projekty ze współpracy z artystami, którzy mają głębszą wrażliwość estetyczną. Może się jednak okazać, że współpraca ta jest trudna, a niekiedy niemożliwa ze względu na zbyt sztywny podział kompetencji i zadań, a także brak pogłębionej podbudowy teoretycznej do prowadzonych badań. Dla badaczy uwikłanych $\mathrm{w}$ pole akademickie narzucające reguły gry projekty artystyczne mogą się wydawać mało atrakcyjne ze względu na problemy z publikacją w naukowych periodykach, trudno także liczyć na naukowe granty (Tamas 2008). Ci jednak, którzy z pasją odważą się przełamywać linie podziału dzielące dziedziny i gatunki, role i kompetencje, wytwory i działania, mogą posmakować owoców, które "kiełkują w scenach i przedmiotach ludzkiego doświadczenia” (Turner 2011: 49).

Dziękuję Pani Profesor Dorocie Rancew-Sikorze za krytyczną lekturę pierwszej wersji tekstu i wszystkie merytoryczne uwagi, które przyczyniły się do powstania artykułu.
Bagley Carl, Cancienne Mary Beth, eds. (2002) Dancing the Data. New York: Peter Lang Publishing, Inc.

Barone Tom, Eisner Elliot W. (2012) Arts Based Research. London: Sage. 
Benedyktowicz Zbigniew (1995) Mit - literatura - antropologia kultury. „Konteksty”, nr 3(4), s. 3-4.

Bielecka-Prus Joanna (2013) Paradygmat partycypacyjny w naukach społecznych. Wykorzystywanie danych wytworzonych przez badanych w analizie jakościowej. „Rocznik Lubuski”, t. 39, nr 1, s. $29-51$.

Bielecka-Prus Joanna (2018) Obcy wśród obcych. Etnografowie w polu badawczym [w:] Tomasz Michał Korczyński, red., Swój-obcy-wróg. Wędrówki w labiryntach kultur. Gdańsk: Wydawnictwo Naukowe Katedra, s. 81-101.

Bochner Arthur P. (2000) Criteria Against Ourselves. „Qualitative Inquiry", vol. 6, no. 2, s. 266-272.

Bochner Arthur, Ellis Carolyn (2003). An Introduction to the Arts and Narrative Research: Art as Inquiry. "Qualitative Inquiry", vol. 9, s. 506-514.

Bonenberg Wojciech (2013) "Arts-Based Research" w prognozowaniu trendów rozwojowych architektury mieszkaniowej. "Środowisko Mieszkaniowe", t. 11, s. 47-54.

Brennan Teresa (1993) History after Lacan. London: Routledge.

Bruner Edward M. (2011) Przė̇ycie i jego ekspresje [w:] Victor W. Turner, Edward M. Bruner, red., Antropologia doświadczenia. Przełożyły Ewa Klekot, Agnieszka Szurek. Kraków: Wydawnictwo UJ, s. 11-39.

Bryda Grzegorz, Martini Natalia (2016) W stronę ontologii pola badań jakościowych. „Przegląd Socjologii Jakościowej”, t. 12, nr 4, s. 24-40.

Burawoy Michael (2005) For Public Sociology. „American Sociological Review", vol. 70, no. 1, s. 4-28.

Cahnamann-Taylor Melisa, Siegesmund Richard, eds. (2008) Arts-Based Research in Education. Foundations For Practice. New York: Routledge.

Chaplin Elizabeth (1994) Sociology and Visual Representation. London: Routledge.

Clifford James (2000) O etnograficznej autokreacji: Conrad i Malinowski. „Konteksty”, nr 1-4, s. 80-105.

Clifford James, Marcus George, eds. (1986) Writing Culture. The Politics and Poetics of Ethnography. Berkeley: University of California Press.
Clough Patricia T. (2000) Comments On Setting Criteria For Experimental Writing. "Qualitative Inquiry”, vol. 6, no. 2, s. 278-291.

Coser Lewis (1963) Sociology Through Literature: an Introductory Reader. Englewood Cliffs, New York: Prentice-Hall.

Czaja Dariusz (2004) Sygnatura i fragment: narracje antropologiczne. Kraków: Wydawnictwo UJ.

Czekaj Rafał (2013) Krytyczna teoria sztuki Theodora W. Adorna. Kraków: Universitas.

Daykin Norma (2004) The Role of Music in an Arts-based Qualitative Inquiry. "International Journal of Qualitative Methods", vol. 3, no. 2, s. 36-44.

Denzin Norman (1997) Interpretive Ethnography: Ethnographic Practices for the 21st Century. Thousand Oaks, CA: Sage.

Denzin Norman (2003) Performance Ethnography: Critical Pedagogy and The Politics of Culture. Thousand Oaks, CA: Sage.

Denzin Norman, Lincoln Yvonna (2009) Wprowadzenie. Dziedzina i praktyka badań jakościowych [w:] Norman Denzin, Yvonna Lincoln, red., Metody badań jakościowych, t. 1, Warszawa: Wydawnictwo Naukowe PWN, s. 16-62.

Eisner Elliot W. (1981) On The Differences Between Scientific and Artistic Approaches To Qualitative Research. „Visual Arts Research", vol. 10, no. 4, s. 5-11.

Eisner, Elliot W. (1997) The promise and perils of alternative forms of data representation. „Educational Researcher”, vol. 26, no. 6, s. 4-10.

Eisner Elliot (2006) Does Arts-Based Research Have a Future? „Studies in Art Education”, vol. 48, no. 1, s. 9-18.

Finley Susan (2003) Arts-Based Inquiry in QI: Seven Years from Crisis to Guerrilla Warfare. "Qualitative Inquiry”, vol. 9, no. 2, s. 281-296.

Finley Susan (2009) Badania posługujace się sztuką. Rewolucyjna pedagogika oparta na performansie [w:] Norman Denzin, Yvonna Lincoln, red., Metody badań jakościowych, t. 2. Warszawa: Wydawnictwo Naukowe PWN, s. 57-80.

Frus, Phyllis (1994) The Politics and Poetics of Journalistic Narrative. New York: Cambridge University Press.

Geertz Clifford (1990) O gatunkach zmaconych: nowe konfiguracje myśli społecznej. „Teksty Drugie: Teoria literatury, krytyka, interpretacja", nr 2, s. 113-130. 
Geertz Clifford (2000) Wiedza lokalna. Dalsze eseje z zakresu antropologii interpretatywnej. Przełożyła Dorota Wolska. Kraków: Wydawnictwo UJ.

Geertz Clifford (2005) Interpretacja kultur. Wybrane eseje. Przełożyła Maria Piechaczek. Kraków: Wydawnictwo UJ.

Glaser Barney (1978) Theoretical Sensitivity. San Francisco: The Sociology Press.

Golka Marian (1995) Socjologia artysty. Poznań: Ars Nova.

Golka Marian (2008) Socjologia sztuki. Warszawa: Difin.

Gouzouasis Peter (2013) The Metaphor of Tonality in Artography. „The UNESCO Observatory E-Journal”, vol. 3, no. 1, s. 1-18.

Gray Ross i in. (2000) The use of research-based theatre in a project related to metastatic breast cancer. "Health Expectations”, vol. 3, no. 2 , s. 137-144.

Irwin Rita L. (2004) A/r/tography as metonymic, metonymic, metissage [w:] Rita. L. Irwin, Alex de Cosson, eds., A/r/tography: Rendering self through arts based living inquiry. Vancouver: Pacific Educational Press, s. 27-38.

Irwin Rita L., Springgay Stephanie (2008) A/r/tography as practice based research [w:] Stephanie Springgay i in., eds., Being with A/r/tography. Rotterdam: Sense Publishers, s. xiiixxvii.

Irwin Rita L., de Cosson Alex, eds. (2004) A/R/Tography: Rendering Self Through Arts-Based Living Inquiry. Vancouver: Pacific Educational Press.

James William (1904) Humanism and Truth. „Mind”, vol. 13, no. 52, s. $457-475$.

Kamiński Stanisław (1992) Nauka i metoda. Pojęcie nauki i klasyfikacja nauk. Lublin: Towarzystwo Naukowe Katolickiego Uniwersytetu Lubelskiego.

Kawalec Anna (2016) Osoba i Nexus. Alfreda Gella antropologiczna teoria sztuki. Lublin: Wydawnictwo KUL.

Konecki Krzysztof (2008) Wizualna teoria ugruntowana. Rodziny kodowania wykorzystywane w analizie wizualnej. "Przegląd Socjologii Jakościowej”, t. 4, nr. 3, s. 89-115.

Krąpiec Mieczysław A. (1979) Ja-człowiek. Zarys antropologii filozoficznej. Lublin: TN KUL.
Lafrenière Darquise, Cox Susan M. (2012) 'If you can call it a poem': toward a framework for the assessment of arts-based works. "Qualitative Inquiry”, vol. 17, no. 4, s. 355-363.

Lahman Maria K. E. (2011) I Am ALL Woma[e]n! "Qualitative Inquiry", vol. 17, no. 2, s. 126-129.

Lawrence-Lightfoot Sara (2005) Reflections on Portraiture: A Dialogue Between Art and Science. „Qualitative Inquiry”, vol. 11, no. 1, s. 3-15.

Leavy Patricia (2018) Metoda spotyka sztukę. Praktyki badawcze oparte na sztuce. Przełożyły: Katarzyna Stanisz, Justyna Kucharska. Warszawa: Narodowe Centrum Kultury.

Lepenis Wolf (1996) Niebezpieczne powinowactwa z wyboru. Eseje na temat historii nauki. Przełożyła Anna Zeidler-Janiszewska. Warszawa: Oficyna Naukowa.

Lincoln Yvonna S. (1995) Emerging Criteria for Quality in Qualitative and Interpretive Research. "Qualitative Inquiry", vol. 1, no. 3, s. $275-289$.

McNiff Shaun (1998) Art-Based Research. London: Jessica Kingsley Publishers.

Mienczakowski Jim (2001). Ethnodrama: Performed research-limitations and potential [w:] Paul Atkinson i in., eds., Handbook of ethnography. Thousand Oaks, CA: Sage, s. 468-476.

Moeran Brian (1996) A Japanese Advertising Agency: An Anthropology of Media and Markets. London, New York: Routledge.

Mulkay Michael J. (1985) The Word and The World: Explorations in The Form of Sociological Analysis. London: Allen and Unwin.

Piantanida Maria, L. McMahon Patricia, Garman Noreen B. (2003) Sculpting the Contours of Arts-Based Educational Research Within a Discourse Community. "Qualitative Inquiry”, vol. 9, no. 2, s. 182-191.

Prendergast Monica (2006) Found poetry as literature review: Research poems on audience and performance. "Qualitative Inquiry", vol. 12, no. 2, s. 369-388.

Prendergast Monica i in. (2009) A Haiku Suite: The Importance of Music Making in The Lives of Secondary School Students. „Music Education Research", vol. 11, no. 3, s. 303-317.

Pryszmont-Ciesielska Martyna (2015) Between Performance and Action - About a Certain Variant of Research that Uses Art (In Connection with a Project about Excluded Mothers). „Teraźniejszość-Człowiek-Edukacja", nr 2(70), s. 97-105. 
Reale Giovanni (1997) Historia filozofii starożytnej. Tom II. Platon i Arystoteles. Przełożył Edward Iwo Zieliński. Lublin: Wydawnictwo KUL.

Reason Peter, Lincoln Yvonna S. (1996) Special Issue: Quality in Human Inquiry. "Qualitative Inquiry”, vol. 2, no. 1, s. 5-136.

Sacks Oliver (1996) Mężczyzna, który pomylił swoja żonę z kapeluszem. Przełożyła Barbara Lindenberg. Poznań : Wydaw. Zysk i S-ka.

Saldaña Johnny (2005) Ethnodrama: an Anthology of Reality Theatre. New York: AltaMira Press.

Saldaña Johnny (2009) The Coding Manual for Qualitative Researchers. Los Angeles, CA: Sage Publications.

Schneider Barbara (2005) Mothers Talk About Their Children with Schizophrenia: A Performance Autoethnography. "Journal of Psychiatric and Mental Health Nursing", vol. 12, no. 3, s. 333-340.

Shostak Marjorie (1981) The Life and Words of a !Kung Woman. Cambridge, MA: Harvard University Press.

Stoller Paul, Olkes Cheryl (1987) In Sorcery's Shadow: A Memoir of Apprenticeship Among the Songhay of Niger. Chicago: University of Chicago Press.
Szkłowski Wiktor B. (1986) Sztuka jako chwyt [w:] Stefania Skwarczyńska, red., Teoria badań literackich za granica. Antologia t. II, cz. III, wyb. Kraków: Znak, s. 95-111.

Szpunar Magdalena (2018) (Nie)potrzebna wrażliwość. Kraków: Uniwersytet Jagielloński.

Tamas Sophie (2008) Writing and Righting Trauma: Troubling the Autoethnographic Voice. „Forum Qualitative Sozialforschung / Forum: Qualitative Social Research", vol. 10, no. 1, art. 22.

Tatarkiewicz Władysław (1970) Sztuka i język: dwa wieloznaczne wyrazy. „Studia Semiotyczne”, t. I, s. 11-22.

Tuan Yi-Fu (1987) Przestrzeń i miejsce. Przełożyła Agnieszka Morawińska. Warszawa: PIW.

Turner Victor W. (2011) Dewey, Dilthey i gra społeczna: szkic z zakresu antropologii doświadczenia [w:] Victor W. Turner, Edward M. Bruner, red., Antropologia doświadczenia. Przełożyły Ewa Klekot, Agnieszka Szurek. Kraków: Wydawnictwo UJ, s. 42-54.

Watson Ashleigh (2016) Directions for Public Sociology: Novel Writing as a Creative Approach. „Cultural Sociology”, vol. 10, no. 4, s. 1-17.

Żmijewski Artur (2007) Stosowane sztuki społeczne. „Krytyka Polityczna" nr 11/12, s. 11-24.

\section{Cytowanie}

Bielecka-Prus Joanna (2020) Badacz jako artysta, artysta jako badacz. Założenia metodologiczne działań artystycznych w procesie badawczym ABR (art-based-research). „Przegląd Socjologii Jakościowej”, t. 16, nr 2, s. 16-34 [dostęp dzień, miesiąc, rok]. Dostępny w Internecie: «www.przegladsocjologiijakosciowej.org〉. DOI: http://dx.doi.org/10.18778/1733-8069.16.2.02

\section{The Researcher as the Artist, the Artist as the Researcher: Methodological Premises of Artistic Activities in the ABR Research Process (Art-Based-Research)}

Abstract: Questioning the epistemological assumptions of positivism and hermeneutics, postmodernism has had a huge impact on the methodology of qualitative research. Not only genres and research roles, but also the boundaries between disciplines have been blurred, as the example of art-based-research (ABR) shows. In ABR, researchers use artistic forms of expression at different stages of data collection, analysis, and presentation. The question of merging the art with science can be analyzed on different levels. In this article, I would like to focus on: 1. explaining the main epistemological and methodological assumptions of ABR; 2. discussing the function of ABR in the social construction of knowledge; 3. specifying the criteria which help evaluate the quality of ABR as well as the difficulties associated with conducting such studies.

Keywords: art in qualitative research, art-based research (ABR), methodology of qualitative research 